\title{
Metabolic Status Regulates Ghrelin Function on Energy Homeostasis
}

\author{
Dana I. Briggs Zane B. Andrews \\ Department of Physiology, Monash University, Clayton, Vic., Australia
}

\begin{abstract}
Key Words
Neuropeptide $Y \cdot$ Pro-opiomelanocortin • Arcuate nucleus $\cdot$ Diet-induced obesity $\cdot$ Calorie restriction . Growth hormone secretagogue receptor - Glucose homeostasis $\cdot$ Food intake $\cdot$ Body weight regulation
\end{abstract}

\begin{abstract}
Ghrelin plays an important role in energy metabolism by regulating food intake, body weight and glucose homeostasis. In this review, we highlight recent developments describing how ghrelin stimulates neuropeptide Y (NPY) neurons, but not pro-opiomelanocortin neurons, to regulate food intake. We describe a novel signaling modality, in which ghrelin activates NPY/agouti-related protein (AgRP) neurons through fatty acid oxidation, reactive oxygen species buffering and mitochondrial function. We hypothesize that this unique system may serve to maintain NPY/AgRP cell function during prolonged negative energy balance. We discuss the idea that the metabolic status plays a key role in ghrelin function. For example, our recent studies illustrate that diet-induced obesity causes ghrelin resistance in arcuate NPY/AgRP neurons. On the other side of the metabolic coin, ghrelin and GOAT knockout models show that ghrelin is required to maintain blood glucose during severe calorie restriction. We propose the hypothesis that ghrelin primarily functions during negative energy balance to maintain whole-body energy homeostasis.

Copyright $\odot 2010$ S. Karger AG, Basel
\end{abstract}

\section{Hypothalamic Regulation of Food Intake}

Food intake and energy metabolism are regulated by a complex interplay between neural networks in the central nervous system and peripheral tissues. Within the central nervous system, food intake is largely controlled by a fine balance between orexigenic and anorexigenic neuropeptides in the arcuate nucleus (ARC) of the hypothalamus. Neuropeptide Y (NPY) and agouti-related protein (AgRP) are coexpressed in neurons of the ARC and are potent orexigenic peptides, whereas pro-opiomelanocortin (POMC) precursor protein in the ARC is cleaved into anorexigenic $\alpha$-melanocyte-stimulating hormone $(\alpha \mathrm{MSH})$ peptides. NPY/AgRP and POMC neurons in the ARC are arguably considered 'first-order' sensory neurons in the control of food intake. These neurons receive, coordinate and respond to changes in varying humoral factors, such as hormones, glucose and fatty acids, associated with different metabolic states. Both NPY/AgRP and POMC neurons project to the paraventricular nucleus (PVN) (see fig. 1).

The critical importance of both NPY/AgRP and POMC neurons in food intake and energy balance is highlighted by elegant conditional gene deletion experiments. Conditional deletion of AgRP neurons in the ARC was achieved by targeting the human diphtheria toxin to the AgRP locus. Adult mice were subsequently treated with diphtheria toxin to destroy AgRP neurons,

\section{KARGER}

Fax +41613061234

E-Mail karger@karger.ch

www.karger.com
(C) 2010 S. Karger AG, Basel

0028-3835/11/0931-0048\$38.00/0

Accessible online at:

www.karger.com/nen
Zane Andrews

Department of Physiology

Monash University, Building 13F, Clayton Campus

Wellington Rd., Clayton, VIC 3800 (Australia)

Tel. +61 39905 8165, Fax +61 39905 2547, E-Mail Zane.andrews @ monash.edu 
Fig. 1. Hypothalamic ARC-PVN circuits controlling food intake and body weight regulation. The ARC houses neurons that coexpress NPY (blue), AgRP (red) and GABA (purple). These neurons stimulate food intake by acting at downstream receptors in the PVN. The ARC nucleus also houses a population of POMC (orange) neurons that produce the anorectic $\alpha \mathrm{MSH}$ peptide. Increased activity of POMC neurons elevates $\alpha \mathrm{MSH}$ in the PVN, which in turn acts on melanocortin 4 receptor (MC4R)-containing neurons in the PVN to suppress food intake. NPY acts on Y1 and $\mathrm{Y} 5$ receptors in the PVN to stimulate food intake, whereas AgRP antagonizes MC4R and prevents the anorectic actions of $\alpha \mathrm{MSH}$. Currently, there is some debate as to whether AgRP is an antagonist or an inverse agonist at the MC4R. Efferent outputs from the PVN project to numerous areas in the brain and brainstem to coordinate feeding behavior, energy expenditure and adiposity. GABA is also an important neurotransmitter secreted from NPY/AgRP neurons in the regulation of food intake. Inhibitory GABA inputs from NPY/AgRP neurons synapse onto POMC neurons within the ARC to suppress the anorectic effects of $\alpha \mathrm{MSH}$ secreted from POMC neurons. Recent studies show that GABA maintains hypothalamic orexigenic tone, as mice engineered to prevent GABA release from NPY/AgRP neurons show a lean anorectic phenotype. NPY neurons respond to circulating hormones and contain many receptor hormones including the ghrelin receptor (GHSR), the insulin receptor (INSR) and the leptin receptor (ObR). It is important to note that although POMC neurons do not express the GHSR $(<8 \%)$, they do respond to insulin and leptin. Neurons in the PVN also contain GHSRs, although the neurochemical phenotype of GHSR-containing neurons in the PVN is unknown. $3 \mathrm{~V}=$ Third ventricle.

which resulted in a rapid reduction in food intake and body weight $[1,2]$. Deletion of POMC neurons in adulthood produced a gradual increase in food intake and body weight [2]. Interestingly, AgRP-deleted mice without any intervention starved to the point of death [2], whereas POMC-deleted mice 'only' became obese [1]. These results imply a greater evolutionary selection pressure to maintain NPY/AgRP cell firing compared to POMC cell firing in the ARC. As a result, it is important to understand the mechanisms that control NPY and POMC cell function. One potential mechanism may be related to hormonal activation; for example, ghrelin induces NPY cell firing but not POMC cell firing. In this review, we examine recent advances in the neuroendocrine actions of ghrelin on hypothalamic food intake and body weight. We will specifically examine the mechanisms through which ghrelin maintains NPY/AgRP firing and suggest that the major role of ghrelin is to maintain hypothalamic energy and glucose homeostasis during negative energy balance and not positive energy

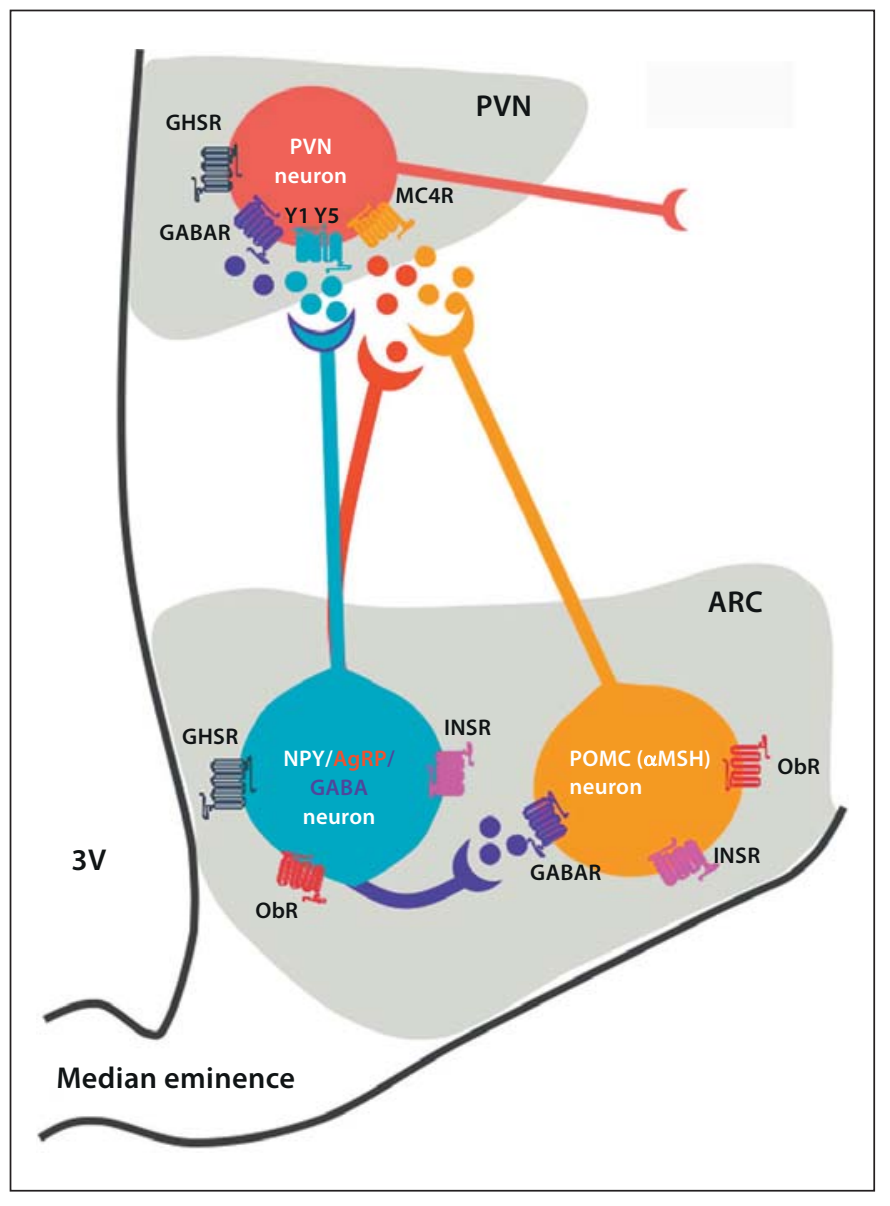

balance. Indeed, our recent results show that diet-induced obesity (DIO) causes ghrelin resistance in arcuate NPY/AgRP neurons.

\section{Ghrelin}

Ghrelin is a 28 -amino-acid orexigenic hormone that stimulates growth hormone release and enhances feeding and weight gain to regulate energy homeostasis [3]. These effects are mediated through activation of the growth hormone secretagogue receptor (GHSR), a 7-transmembrane G-protein-coupled receptor [4]. Pro-ghrelin mRNA is highly expressed in the stomach with lower levels also found in the duodenum, jejunum, ileum and colon $[5,6]$. There is some evidence that ghrelin is also produced in the hypothalamic ARC, although the significance of hypothalamic ghrelin remains enigmatic [7]. Pro-ghrelin requires posttranslational acylation with $\mathrm{n}$-octanoic acid or n-decanoic acid at the third serine for biological activ- 
Fig. 2. The actions of ghrelin on ARCPVN hypothalamic circuits controlling food intake and body weight. Ghrelin produced in the stomach travels in the circulation and crosses the blood-brain barrier to activate NPY/AgRP neurons in the ARC. Ghrelin-induced activation of NPY/AgRP neurons increases NPY and AgRP peptide release from nerve terminals in the PVN and increases food intake by activating $\mathrm{Y} 1$ and Y 5 receptors and antagonizing MC4Rcontaining neurons, respectively. Ghrelin also increases the NPY and AgRP mRNA concentrations, in order to maintain sufficient peptide pools for release. Ghrelin further enhances the orexigenic tone by increasing GABA inhibitory postsynaptic currents and inhibitory synaptic contacts on POMC neurons. This inhibition of POMC neuronal activity prevents the suppressive effect of $\alpha \mathrm{MSH}$ on food intake and thus allows greater orexigenic drive. Ghrelin also stimulates growth hormone $(\mathrm{GH})$ release by activating growth hormone releasing hormone (GHRH) neurons in the ARC or by directly activating somatotrophs in the anterior pituitary. The GHSR is also found in the PVN and ghrelin can directly activate PVN neurons independently from its actions on NPY/ AgRP neurons in the ARC. While it is well known that ghrelin acts in the ARC to stimulate food intake, the direct actions of ghrelin in the PVN are unknown. Current evidence suggests the direct actions of ghrelin in the PVN may control body weight and adiposity independently of its actions in the ARC (see text for detail). $3 \mathrm{~V}=$ Third ventricle.

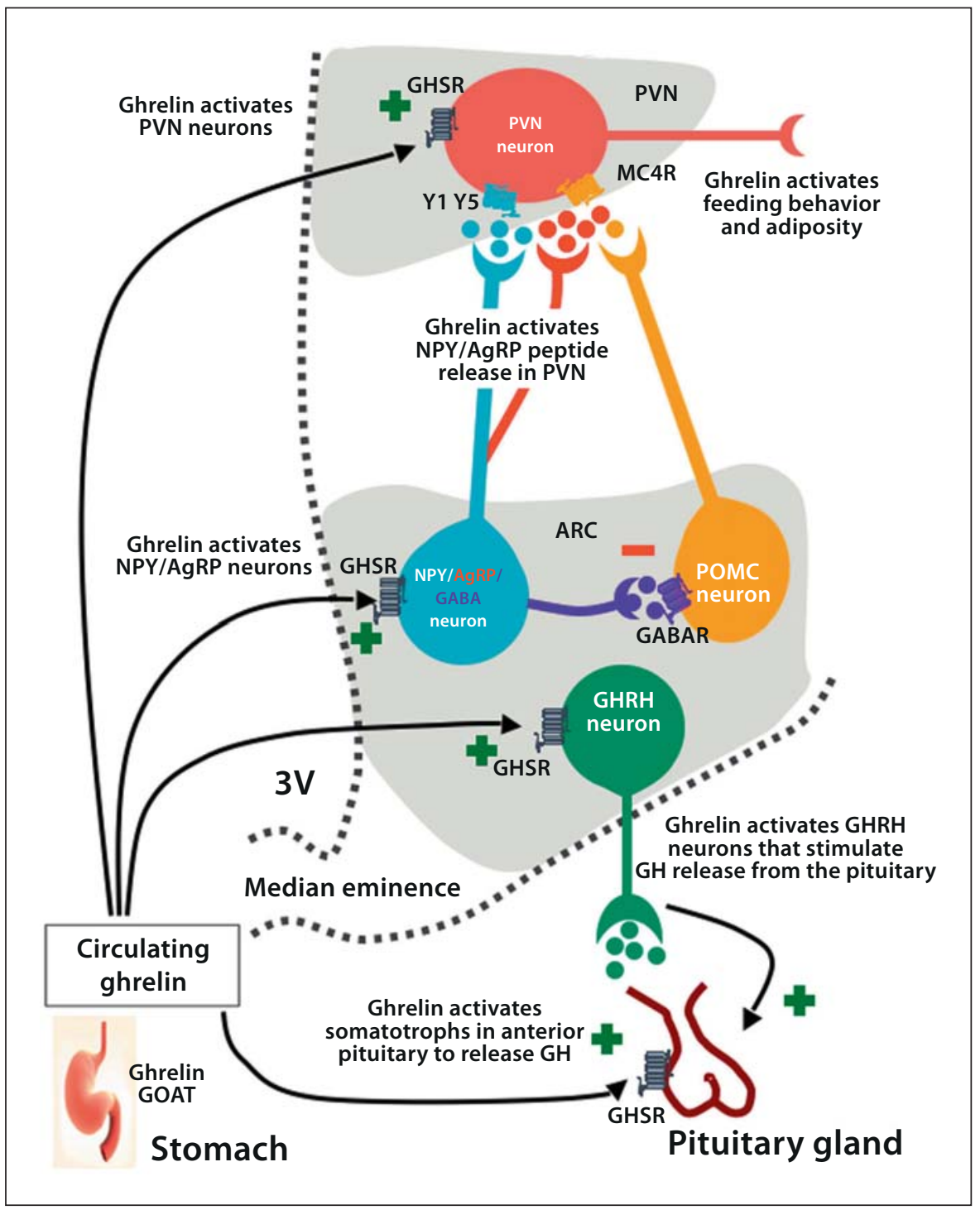

ity [4]. Ghrelin is acylated by the enzyme ghrelin O-acyltransferase (GOAT), a highly conserved member of the membrane-bound O-acyltransferase family of acyltransferases that attach fatty acids to lipids and proteins $[8,9]$. As expected, the relative tissue distribution of GOAT mRNA matches that of ghrelin [9]; GOAT mRNA is highest in the stomach, but is also detectable in the small intestine, colon and pancreas $[8,9]$. Dual-label histochemical analyses show that GOAT and ghrelin colocalize to the same cells within the stomach and duodenum [10]. In these cells, GOAT is localized to the endoplasmic reticulum [9], where pro-ghrelin is acylated. GOAT can acylate pro-ghrelin with other fatty acid substrates besides octanoate and this is likely a function of dietary fatty acid availability [11]. Once ghrelin is acetylated with a medium-chain fatty acid, it is transported to the Golgi apparatus and cleaved by prohormone convertase $1 / 3$ to form 28 -amino-acid mature ghrelin [12]. The plasma des-acyl ghrelin levels are about fourfold higher than acyl ghrelin, suggesting that the des-acyl form of ghrelin is dominant in the blood [13], although the mechanisms that control the rate at which acyl-ghrelin becomes des-acylated are unknown.

Consistent with ghrelin's well-characterized roles in regulating growth hormone function and energy homeostasis, the strongest expression of GHSR mRNA is in the hypothalamus [14] with highest expression in the ARC [15]. Here, the GHSR is expressed on growth hormone 
releasing hormone $(\mathrm{GHRH})$-expressing neurons $[16,17]$, tyrosine-hydroxylase-expressing neurons $[15,18]$ and NPY/AgRP neurons [17].

Ghrelin's effects on food intake and energy homeostasis are largely mediated by arcuate NPY/AgRP neurons. In these neurons, ghrelin administration induces Fosimmunoreactivity [19-21], action potential firing [7, 19] and increased expression of NPY and AgRP mRNA [2224]. Ghrelin does not stimulate feeding in mice that lack both NPY and AgRP $[25,26]$, confirming that NPY and AgRP neurons mediate ghrelin's orexigenic actions (fig. 2).

The stimulatory effects of ghrelin on orexigenic NPY/ AgRP neurons are complemented by reduced POMC neuronal activity via inhibitory $\gamma$-aminobutyric acid (GABA)ergic inputs from NPY/AgRP neurons [7]. Ablation of AgRP neurons or AgRP neuron-specific deletion of vesicular GABA transporter removes the inhibitory tone onto postsynaptic POMC cells, allowing unopposed activation of the melanocortin system and subsequent anorexia [27]. GABA-mediated electrophysiological inhibition of POMC neurons by NPY/AgRP neurons is accompanied by changes in POMC neuronal synaptic plasticity [19].

\section{Mechanisms of Ghrelin's Action on NPY Neurons}

Because AgRP-ablated adult mice starved to death [2] and POMC-ablated adult mice 'only' became obese [1], we hypothesized that NPY/AgRP neurons evolved particular intracellular mechanisms to maintain firing under conditions of negative energy balance. One key endocrine signal may be ghrelin, as the GHSR is located on NPY/AgRP but not on most POMC neurons $(<8 \%)[17]$ and ghrelin is increased in the plasma of fasted and calorie-restricted mice [3, 28, 29]. Not all studies show a consistent increase in plasma ghrelin in response to negative energy balance in rodents and humans [11,30], which may be related to assay differences [31]. The difference between NPY/AgRP and POMC neurons may be related to ghrelin-induced intracellular activation of fatty acid oxidation pathways and reactive oxygen species (ROS) buffering in NPY/AgRP neurons but not POMC neurons [19, 32-34]. Ghrelin does not activate these pathways in POMC neurons, as most POMC neurons lack the GHSR [17]. Ghrelin activates AMP-activated kinase (AMPK) in the hypothalamus $[33,35]$ and specifically activates AMPK in NPY neurons via increased intracellular calcium [36]. AMPK is an intracellular energy sensor that switches off ATP-consuming pathways and switches on ATP-producing pathways such as glucose uptake and fatty acid oxidation [37]. Downstream actions of AMPK include phosphorylation of acetyl CoA carboxylase (ACC), which causes the suppression of malonyl CoA and disinhibition of carnitine palmitoyl transferase 1 (CPT1). Increased CPT1 increases fatty acid acyl-CoA transport into mitochondria for oxidation. Indeed, both CPT1 and malonyl CoA play important roles in regulating food intake, as inhibition of CPT1 decreases food intake [38], as does activation of malonyl CoA [39]. Because ghrelin activates AMPK in NPY neurons, we hypothesized it would allow downstream activation of CPT1 to drive food intake. Ghrelin activates CPT1 (via AMPK) in the hypothalamus and CPT1 activation is required for ghrelin to stimulate food intake $[19,34]$. Ghrelin also activates uncoupling protein-2 (UCP2)-dependent mitochondrial respiration, driven by the fatty acid oxidation of palmitate. UCP2 is required to permit CPT1 activation and subsequent mitochondrial-fatty-aciddriven respiration [19]. Furthermore, ghrelin initially increases the fatty acyl-CoA concentration in the hypothalamus as a substrate for fatty acid oxidation in mitochondria. We discovered that UCP2, specifically in NPY/ AgRP neurons, is required to buffer excessive ROS production generated by ghrelin-induced fatty acid oxidation [19]. Thus, ghrelin activation of this AMPK-CPT1UCP2 pathway permits increased fatty acid oxidation while buffering increased ROS in NPY neurons but not POMC neurons. This increase in mitochondrial activity and ROS buffering permits an increase in NPY and AgRP mRNA gene expression, sustained NPY/AgRP cell firing and elevated food intake. As such, we propose that the ability of ghrelin to activate the AMPK-CPT1-UCP2 pathway in NPY/AgRP neurons, but not POMC neurons, is the critical mechanism that allows sustained NPY/ AgRP firing during starvation. This appears to be a selective advantage to maintain NPY/AgRP cell function especially considering that ablation of NPY/AgRP results in starvation and death, and ablation of POMC 'only' results in obesity.

It should be mentioned that ghrelin, GHSR and GOAT knockout mice show little or no obvious impairment in food intake and results from these studies suggest ghrelin's major role is in glucose homeostasis [29, 40-43]. However, it is too early to dismiss an endogenous physiological role for ghrelin in food intake based solely on these knockout data. Indeed, initial NPY, AgRP and double NPY/AgRP knockouts also showed no obvious defect in food intake, suggesting compensatory mechanisms 
through development ensure food intake pathways are stable in adulthood despite the lack of NPY, AgRP or both NPY and AgRP. A similar mechanism may be occurring in the ghrelin, GHSR and GOAT knockouts.

Intriguingly, we observed increased ROS production in POMC neurons compared to NPY neurons under basal conditions, suggesting POMC neurons might be prone to free-radical-induced degeneration over time [19]. The decline in functional POMC neurons over time may promote increased orexigenic NPY tone and lead to hyperphagia and weight gain associated with ageing.

\section{DIO Causes Ghrelin Resistance in NPY/AgRP Neurons}

The studies above highlight the mechanism through which ghrelin promotes NPY/AgRP neuronal firing. However, little is known about how ghrelin affects NPY/ AgRP function during DIO, which is important as several components of the neuroendocrine ghrelin system are disturbed by DIO. Firstly, peripherally administered ghrelin does not stimulate food intake in mice fed a highfat diet (HFD) for 16 weeks [44]. Secondly, DIO impairs the transport of ghrelin across the blood-brain barrier [45]. Lower circulating ghrelin in conjunction with impaired transport into the brain results in less ghrelin signal at the level of GHSR-containing neurons. Thirdly, DIO causes disruption of hypothalamic appetite-regulating circuits, as mice bred to develop DIO have reduced density of NPY/AgRP and POMC axons innervating the PVN [46]. Fourthly, DIO suppresses the basal AMPK activity in the hypothalamus, although this suppression is only significant in the PVN $[47,48]$. Taken together, these data suggest the ghrelin-AMPK-NPY/AgRP system is impaired by DIO. This led us to hypothesize that (1) the hypothalamic circuitry controlling food intake becomes resistant to ghrelin during obesity, and (2) that ghrelin resistance is a centrally mediated phenomenon, which alters NPY/AgRP circuits.

We recently demonstrated that DIO suppresses the neuroendocrine ghrelin system and causes ghrelin resistance in ARC neurons [49]. In DIO mice, ghrelin and GOAT mRNA in the stomach and plasma ghrelin are all decreased $[49,50]$. Reduced circulating ghrelin in DIO mice is compounded by decreased expression of hypothalamic GHSR [49]. The GHSR has high constitutive activity [51] and contributes to the basal regulation of food intake and body weight even in the absence of ghrelin ligand binding [52]. Thus, decreased hypothalamic GHSR mRNA expression may further contribute to hypotha- lamic ghrelin resistance due to lower basal constitutive activity [51] and less GHSR, to which ghrelin can bind (fig. 3).

In DIO mice, central ghrelin neither induces activation of ARC neurons as demonstrated by Fos immunoreactivity, nor increases expression of hypothalamic NPY and AgRP mRNA nor induces feeding in either the light or dark phases [49] (fig. 3). Ghrelin administration increases NPY activity in ex vivo hypothalamic slices from chow-fed mice, likely increasing the release of NPY and AgRP at nerve terminals in the PVN [7]. We showed that ghrelin does not induce AgRP or NPY peptide secretion in hypothalamic explants from DIO mice compared to chow-fed controls [49]. To determine whether downstream NPY/AgRP neural targets are intact, we delivered NPY directly into the lateral ventricle and this was able to induce food intake in both chow-fed and DIO mice. Thus, in DIO mice, ghrelin resistance in NPY/AgRP neurons is the result of decreased NPY/AgRP peptide release at synaptic targets in the PVN. Collectively, our data demonstrate that central hypothalamic ghrelin resistance is a product of two presumably dependent mechanisms. First, DIO suppresses the neuroendocrine ghrelin axis and second, DIO impairs NPY/AgRP neuronal function in the ARC of the hypothalamus and reduces responsiveness to ghrelin. The exact hypothalamic mechanisms behind this phenomenon are unclear but may be related to endocrine changes that occur in DIO such hyperglycemia and hyperinsulinemia. Central infusion of insulin during fasting prevents upregulation of NPY mRNA expression and reduces immunoreactive NPY concentrations in the PVN [53]. Central insulin infusion also reduces both hyperphagia and overexpression of hypothalamic NPY mRNA in diabetic rats [47]. Central insulin infusion does not affect plasma insulin, indicating that insulin acts locally to inhibit hypothalamic NPY mRNA expression. These effects may be mediated by reduced AMPK activity in ARC NPY/AgRP neurons, as central infusion of glucose or insulin inhibits the activity of $\alpha 2 \mathrm{AMPK}$ activity in the ARC and PVN [54]. Knockdown of $\alpha 1$ and $\alpha 2$ AMPK subunits decreases expression of NPY and AgRP mRNA, resulting in reduced feeding and weight loss [54]. Finally, peripheral infusion of glucose, free fatty acids or insulin during euglycemia suppresses plasma ghrelin, but importantly, these effects are mediated by insulin $[55,56]$. Collectively, these data suggest that glucose and insulin are important negative regulators of ghrelin in the plasma and ghrelin activation of NPY/AgRP firing. Future studies are required to prove that hyperglycemia and hyperinsu- 
Fig. 3. DIO causes ghrelin resistance in ARC neurons but not PVN neurons. After 12 weeks on an HFD, circulating ghrelin, ghrelin mRNA and GOAT mRNA in the stomach and GHSR mRNA in the hypothalamus are all reduced, indicating that the neuroendocrine ghrelin system is suppressed during DIO. Further, ghrelin neither activates NPY/AgRP neurons nor NPY/AgRP peptide release. As a result, central ghrelin does not increase food intake in DIO mice. It is currently unknown whether DIO prevents ghrelin activation of GABA inhibitory currents on POMC neurons. However, because ghrelin does not increase food intake in DIO mice, it is presumed that ghrelin does not inhibit POMC neurons via GABA inhibitory inputs from NPY/AgRP neurons. This will maintain the suppressive effects of the POMC peptide, $\alpha \mathrm{MSH}$, on food intake. Interestingly, ghrelin still activates Fos-positive neurons in the PVN in DIO mice despite no observable effect in the ARC. Because central ghrelin does not increase food intake in DIO, the Fos activation in the PVN is most likely not involved in stimulating food intake. We believe the direct actions of ghrelin in the PVN may control body weight and adiposity independently of feeding behavior. The mechanisms causing NPY/AgRP resistance to ghrelin in DIO remain unknown, but may be related to hyperglycemia and hyperinsulinemia associated with DIO (see text for details under the heading 'DIO Causes Ghrelin Resistance in NPY/AgRP Neurons'). In addition to ghrelin's effects on the appetite-stimulating neurons in the ARC, ghrelin does not stimulate GHRH neurons and growth hormone $(\mathrm{GH})$ release from the pituitary. Because DIO also decreases the GHSR mRNA content in the anterior pituitary, it is assumed that the anterior pituitary does not secrete $\mathrm{GH}$ in response to ghrelin in DIO, although this requires experimental validation.

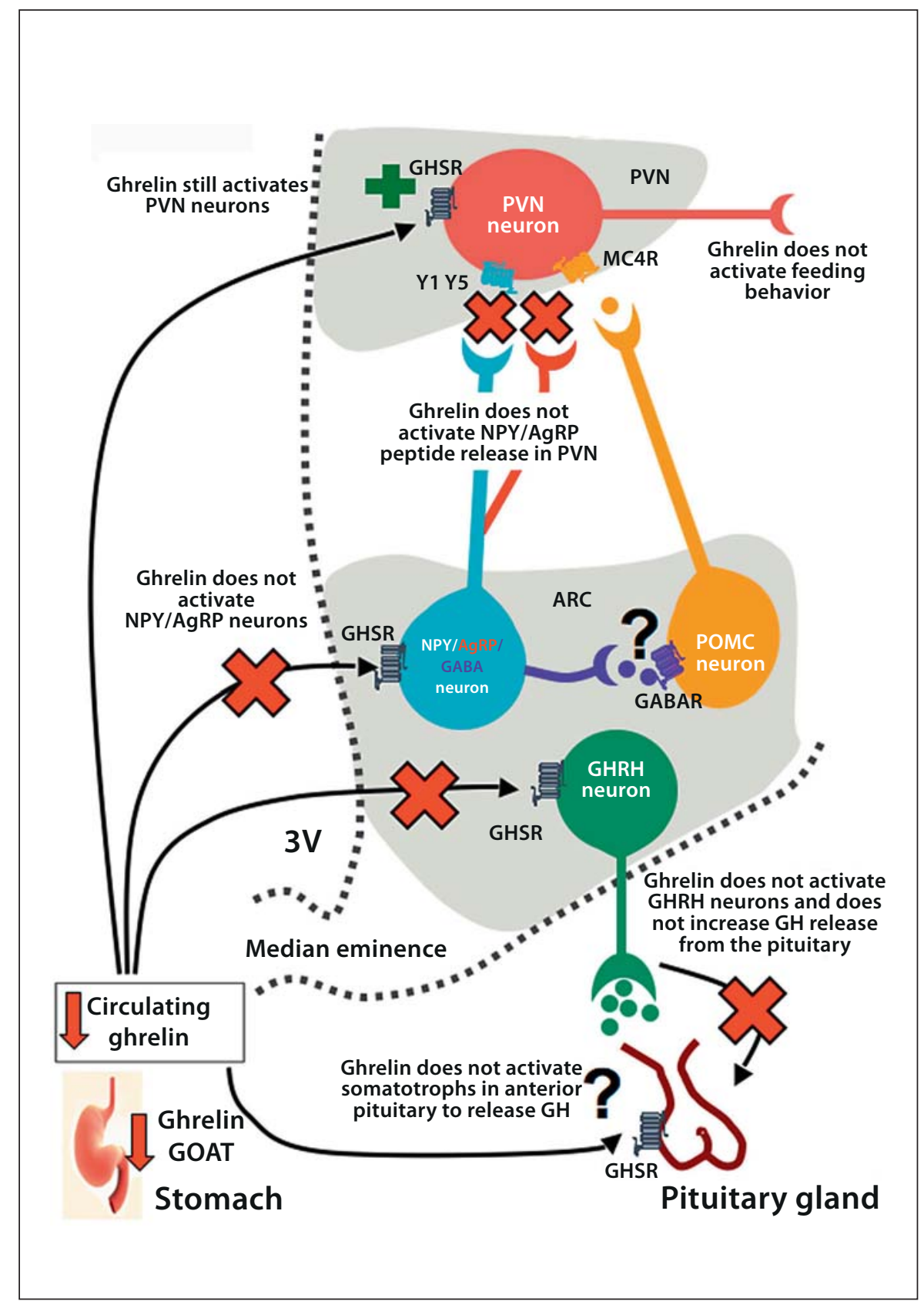

linemia in DIO cause ghrelin resistance in NPY/AgRP neurons.

Interestingly, central ghrelin increases plasma growth hormone in chow-fed mice but not in DIO mice [49]. This supports our hypothesis that DIO promotes hypothalamic ghrelin resistance, and further that hypothalamic ghrelin resistance is not only confined to appetite-regulating pathways but also affects other neurons expressing
GHSR. As ghrelin was injected intracerebroventricularly, we believe ghrelin does not activate GHRH neurons in the ARC in DIO, although this requires experimental proof. Further, DIO decreases in pituitary GHSR expression [57], showing that DIO reduces ghrelin-induced growth hormone release at both the hypothalamic and pituitary levels. 

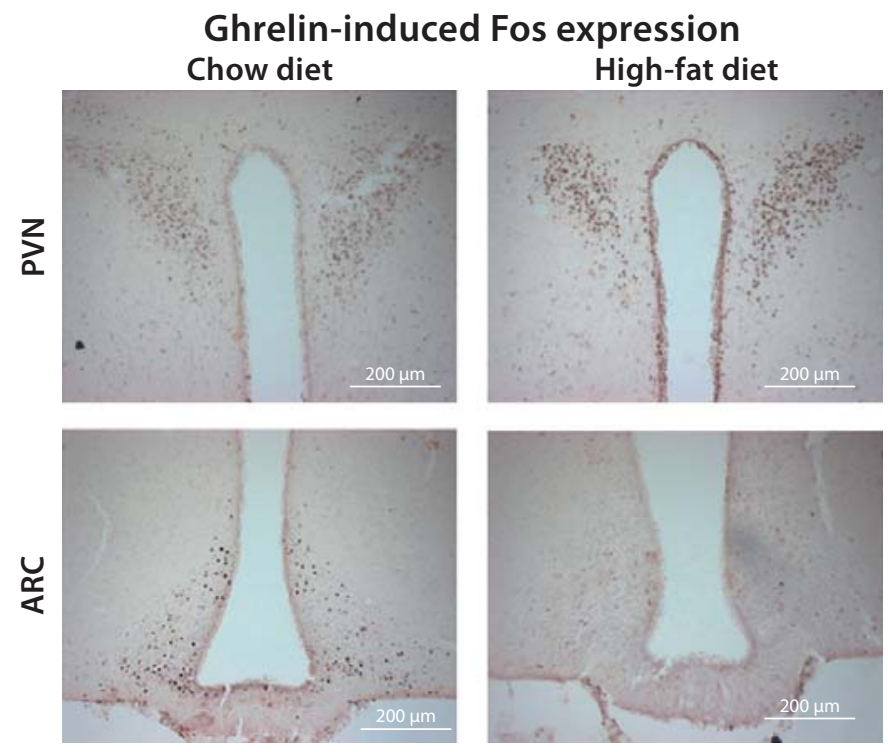

Fig. 4. Ghrelin does not activate Fos in the ARC of DIO mice. These photographs show that central ghrelin activates a normal Fos response in the ARC of chow-fed but not high-fat-fed mice, indicating that ARC neurons are resistant to ghrelin-induced activation. On the other hand, central ghrelin produces a normal Fos response in the PVN of both chow-fed and high-fat-fed mice. This indicates that the PVN responds directly to ghrelin, presumably through GHSRs present in the PVN. The figure is reproduced with permission from Briggs et al., 2010 [49], copyright 2010, The Endocrine Society.

\section{Ghrelin Mediates Food Intake and Body Weight Independently}

Theander-Carrillo et al. [58] showed that chronic central ghrelin increases fat deposition independently of changes in food intake, as shown by pair-feeding experiments. Central ghrelin increased the respiratory quotient, indicating greater carbohydrate metabolism, without alterations in total energy expenditure or spontaneous physical activity. Central ghrelin increased the white adipose tissue mRNA levels of the fat-storage-promoting enzymes lipoprotein lipase (LPL), ACC $\alpha$, fatty acid synthase and stearoyl-CoA desaturase-1 in both ad libitum and pair-fed animals.

The effect of ghrelin on adiposity is independent of ghrelin-induced feeding mediated by NPY/AgRP peptide release, as NPY-induced food intake only increases body weight in ad-libitum-fed mice but not pair-fed mice [59]. In addition, ghrelin increases body weight in NPY-deficient mice [60], indicating that NPY activation in the ARC is not involved in ghrelin-induced fat accumulation.
Thus, ghrelin's effect on body weight and adiposity is not mediated by ghrelin-induced NPY activity in the ARC and subsequent NPY-induced food intake. These body weight effects are presumably mediated by additional hypothalamic nuclei.

The PVN is a candidate hypothalamic nucleus that regulates ghrelin-induced weight gain. GHSR is expressed in the PVN [15], indicating that ghrelin directly activates these neurons. Recent studies examined the role of ghrelin in the PVN by selectively knocking down GHSRs in vivo (60\% knockdown) using RNA interference. GHSR knockdown does not affect daily food intake but significantly reduces body weight and blood ghrelin levels [61]. Thus, direct ghrelin activation of GHSR in the PVN regulates body weight independently of food intake. Further, central ghrelin injection in DIO mice activates Fos-positive neurons in the PVN, even though ARC neurons are not activated [49] (fig. 4). In DIO conditions, we hypothesize that ghrelin increases adiposity through PVN signaling despite ghrelin resistance in the ARC. Therefore, we suggest that the PVN is presumably both a 'first-order' and 'secondorder' nucleus responding directly to ghrelin that has gained access in the cerebrospinal fluid (first order) and responding indirectly to ghrelin-induced NPY and AgRP release (second order). Collectively, these data demonstrate that central ghrelin increases energy partitioning and regulates adipocyte metabolism, independently of ghrelin's actions on NPY neurons.

The hypothalamic actions of ghrelin in energy metabolism are twofold: (1) ghrelin acts via NPY/AgRP neurons in the ARC to increase food intake and (2) ghrelin acts directly on GHSR-containing neurons in the PVN to increase body weight and adiposity. Further studies are required to elucidate the different functions of GHSR signaling in different hypothalamic nuclei.

\section{Ghrelin Is Critical for Survival under Calorie Restriction - Insights from Knockout Studies}

Despite the importance of the ghrelin system in regulating food intake and body weight, mice lacking ghrelin, GOAT or GHSR show no, or only a modest, metabolic phenotype [18, 29, 42, 62-65]. Under conditions of standard laboratory housing these mice have normal life span and food intake. Slight differences in body weight have been observed in some but not all cases. Studies show that $\mathrm{GHSR}^{-/-}$mice but not ghrelin ${ }^{-/-}$mice have significantly reduced body weight on a regular chow diet $[42,65]$, and this difference may be related to the consti- 
tutive signaling properties of the GHSR in the absence of ligand binding [52]. However, using a different $\mathrm{GHSR}^{-/-}$ mouse line, Zigman et al. [64] did not witness any difference in body weight on a standard chow diet. Moreover, Pfluger et al. [66] only found a significant difference in body weight when ghrelin ${ }^{-/}$or $\mathrm{GHSR}^{-/-}$mice were bred together to generate double-knockout mice.

Modest changes are observed when ghrelin ${ }^{-/-}$and $\mathrm{GHSR}^{-/-}$mice are subjected to an HFD [42, 63, 64]. Ghre$\mathrm{lin}^{-/-}$mice gain less weight and had greater energy expenditure on an HFD than their wild-type controls despite having the same food intake [62]. However, recent studies using congenic ghrelin ${ }^{-/-}$mice outbred on a C57/B6 ( $\mathrm{n}=$ 10) background showed no protection against HFD [42]. $\mathrm{GHSR}^{-/-}$mice also gain less weight on HFD, and are slightly hypophagic [64], although Sun et al. [42] observed a reduction in body weight gain in GHSR-/- mice relative to wild-type mice on HFD in the absence of hypophagia or differences in energy expenditure. The equivocal results on body weight from knockout animals on either standard chow or HFD might be related to strain differences.

Studies from knockout mice illustrate that the major role of ghrelin is not to regulate food intake or body weight but rather to regulate glucose homeostasis. Ablation of ghrelin in $o b / o b$ mice fails to reduce hyperphagia and body weight but decreases hyperglycemia and improves peripheral insulin sensitivity [41]. Deletion of the GHSR markedly reduces blood glucose and plasma insulin upon fasting, suggesting that GHSR deletion increases insulin sensitivity [42]. This is in accordance with clinical studies showing that low plasma ghrelin is associated with insulin resistance [67-69].

Under $50-60 \%$ calorie restriction mice lacking ghrelin, GHSR and GOAT have lower blood glucose levels than their wild-type littermates $[29,42]$. Recent studies in $\mathrm{GOAT}^{-1-}$ mice, the enzyme that acylates pro-ghrelin, show that an essential function of ghrelin is to maintain survival during severe calorie restriction [29]. These mice lacked acylated ghrelin and could not control blood glucose during severe calorie restriction. After 7-8 days of calorie restriction the mice appeared moribund and had to be euthanized. Infusion of ghrelin or growth hormone normalized blood glucose to wild-type levels. Interestingly, $\mathrm{GOAT}^{-/}$mice showed no defect in food intake under normal dietary or calorie-restricted conditions. These studies clearly illustrate that ghrelin is required to maintain survival under conditions of severe negative energy balance, not by increasing food intake but rather by maintaining blood glucose. In support of this notion, the fast- ed blood glucose levels are not different in $\mathrm{GHSR}^{-/-}$mice on an HFD but are lower in calorie-restricted $\mathrm{GHSR}^{-/-}$ mice compared to wild-type controls [42]. Our hypothesis is supported by increased plasma ghrelin during negative energy balance. Since the neuroendocrine ghrelin system is suppressed in DIO, we postulate that ghrelin does not play a major role in the pathogenesis of diabetes.

Current ghrelin, GHSR and GOAT knockout models suggest that ghrelin plays a minimal role in food intake and body weight, despite the wealth of literature showing that exogenous ghrelin administration increases food intake and adiposity. However, it is too early to dismiss a role for ghrelin in food intake and body weight based on these knockout models. An important development to understand the true physiological role of ghrelin will be the generation of a temporal ghrelin knockout mouse. This transgenic mouse line will sidestep the issue of compensatory developmental mechanisms that may ensure food intake and body weight gain after ghrelin deletion. This is important as neonatal ablation of NPY/AgRP neurons has minimal effects on feeding, whereas ablation in adults causes rapid starvation [2].

\section{Conclusions}

The research highlighted above now points towards ghrelin as a key modulator of energy metabolism during negative energy balance and starvation. Most notably, knockout models show that ghrelin is indispensable for blood glucose control during starvation. Whether or not ghrelin plays a role in the pathogenesis of diabetes, by promoting hyperglycemia, remains to be determined. In DIO, the actions of ghrelin to increase food intake in the brain are suppressed at the level of the hypothalamic ARC nucleus. Furthermore, ghrelin peptide in the circulation, as well as ghrelin and GOAT mRNA in the stomach and GHSR in the hypothalamus are all reduced. These observations further support the important role of ghrelin in negative energy balance, rather than positive energy balance, i.e. obesity. Future research is required to determine whether ghrelin resistance occurs in other regions of the brain that express the GHSR.

\section{Acknowledgements}

This work was supported by a Monash Fellowship, Monash University, Australia; Monash University Strategic Grant Scheme - Early Career Development Award and NHMRC grant (NHMRC 546131) to Z.B.A. 


\section{References}

1 Gropp E, Shanabrough M, Borok E, Xu AW, Janoschek R, Buch T, Plum L, Balthasar N, Hampel B, Waisman A, Barsh GS, Horvath TL, Bruning JC: Agouti-related peptide-expressing neurons are mandatory for feeding. Nat Neurosci 2005;8:1289-1291.

$\checkmark 2$ Luquet S, Perez FA, Hnasko TS, Palmiter RD: Npy/agrp neurons are essential for feeding in adult mice but can be ablated in neonates. Science 2005;310:683-685.

3 Tschop M, Smiley DL, Heiman ML: Ghrelin induces adiposity in rodents. Nature 2000; 407:908-913.

-4 Howard AD, Feighner SD, Cully DF, Arena JP, Liberator PA, Rosenblum CI, Hamelin M, Hreniuk DL, Palyha OC, Anderson J, Paress PS, Diaz C, Chou M, Liu KK, McKee KK, Pong SS, Chaung LY, Elbrecht A, Dashkevicz M, Heavens R, Rigby M, Sirinathsinghji DJ, Dean DC, Melillo DG, Patchett AA, Nargund R, Griffin PR, DeMartino JA, Gupta SK, Schaeffer JM, Smith RG, Van der Ploeg LH: A receptor in pituitary and hypothalamus that functions in growth hormone release. Science 1996;273:974-977.

5 Kojima M, Hosoda H, Date Y, Nakazato M, Matsuo H, Kangawa K: Ghrelin is a growthhormone-releasing acylated peptide from stomach. Nature 1999;402:656-660.

-6 Date Y, Kojima M, Hosoda H, Sawaguchi A, Mondal MS, Suganuma T, Matsukura S, Kangawa K, Nakazato M: Ghrelin, a novel growth hormone-releasing acylated peptide, is synthesized in a distinct endocrine cell type in the gastrointestinal tracts of rats and humans. Endocrinology 2000;141:42554261.

7 Cowley MA, Smith RG, Diano S, Tschop M, Pronchuk N, Grove KL, Strasburger CJ, Bidlingmaier $M$, Esterman $M$, Heiman $M L$, Garcia-Segura LM, Nillni EA, Mendez P, Low MJ, Sotonyi P, Friedman JM, Liu H, Pinto S, Colmers WF, Cone RD, Horvath TL: The distribution and mechanism of action of ghrelin in the CNS demonstrates a novel hypothalamic circuit regulating energy homeostasis. Neuron 2003;37:649-661.

8 Gutierrez JA, Solenberg PJ, Perkins DR, Willency JA, Knierman MD, Jin Z, Witcher DR, Luo S, Onyia JE, Hale JE: Ghrelin octanoylation mediated by an orphan lipid transferase. Proc Natl Acad Sci USA 2008 105:6320-6325.

\$ Yang J, Brown MS, Liang G, Grishin NV, Goldstein JL: Identification of the acyltransferase that octanoylates ghrelin, an appetitestimulating peptide hormone. Cell 2008; 132: 387-396.

-10 Sakata I, Yang J, Lee CE, Osborne-Lawrence S, Rovinsky SA, Elmquist JK, Zigman JM: Colocalization of ghrelin O-acyltransferase and ghrelin in gastric mucosal cells. Am J Physiol Endocrinol Metab 2009;297:E134E141.
11 Kirchner H, Gutierrez JA, Solenberg PJ, Pfluger PT, Czyzyk TA, Willency JA, Schurmann A, Joost HG, Jandacek RJ, Hale JE, Heiman ML, Tschop MH: Goat links dietary lipids with the endocrine control of energy balance. Nat Med 2009;15:741-745.

12 Zhu X, Cao Y, Voogd K, Steiner DF: On the processing of proghrelin to ghrelin. J Biol Chem 2006;281:38867-38870.

13 Murakami N, Hayashida T, Kuroiwa T, Nakahara K, Ida T, Mondal MS, Nakazato M, Kojima M, Kangawa K: Role for central ghrelin in food intake and secretion profile of stomach ghrelin in rats. J Endocrinol 2002; 174:283-288.

14 Guan XM, Yu H, Palyha OC, McKee KK, Feighner SD, Sirinathsinghii DJ, Smith RG, Van der Ploeg LH, Howard AD: Distribution of mRNA encoding the growth hormone secretagogue receptor in brain and peripheral tissues. Brain Res Mol Brain Res 1997;48:2329.

15 Zigman JM, Jones JE, Lee CE, Saper CB, Elmquist JK: Expression of ghrelin receptor mRNA in the rat and the mouse brain. J Comp Neurol 2006;494:528-548.

16 Tannenbaum GS, Lapointe M, Beaudet A, Howard AD: Expression of growth hormone secretagogue-receptors by growth hormonereleasing hormone neurons in the mediobasal hypothalamus. Endocrinology 1998;139: 4420-4423.

17 Willesen MG, Kristensen P, Romer J: Co-localization of growth hormone secretagogue receptor and NPY mRNA in the arcuate nucleus of the rat. Neuroendocrinology 1999; 70:306-316.

18 Shuto Y, Shibasaki T, Otagiri A, Kuriyama H, Ohata H, Tamura H, Kamegai J, Sugihara H, Oikawa S, Wakabayashi I: Hypothalamic growth hormone secretagogue receptor regulates growth hormone secretion, feeding, and adiposity. J Clin Invest 2002;109:14291436.

19 Andrews ZB, Liu ZW, Walllingford N, Erion DM, Borok E, Friedman JM, Tschop MH, Shanabrough M, Cline G, Shulman GI, Coppola A, Gao XB, Horvath TL, Diano S: UCP2 mediates ghrelin's action on NPY/AGRP neurons by lowering free radicals. Nature 2008;454:846-851.

20 Hewson AK, Dickson SL: Systemic administration of ghrelin induces Fos and EGR-1 proteins in the hypothalamic arcuate nucleus of fasted and fed rats. J Neuroendocrinol 2000;12:1047-1049.

21 Wang L, Saint-Pierre DH, Tache Y: Peripheral ghrelin selectively increases fos expression in neuropeptide $\mathrm{Y}$ - synthesizing neurons in mouse hypothalamic arcuate nucleus. Neurosci Lett 2002;325:47-51.

-22 Kamegai J, Tamura H, Shimizu T, Ishii S, Sugihara H, Wakabayashi I: Central effect of ghrelin, an endogenous growth hormone secretagogue, on hypothalamic peptide gene expression. Endocrinology 2000;141:47974800.
23 Kamegai J, Tamura H, Shimizu T, Ishii S, Sugihara H, Wakabayashi I: Chronic central infusion of ghrelin increases hypothalamic neuropeptide $\mathrm{Y}$ and agouti-related protein mRNA levels and body weight in rats. Diabetes 2001;50:2438-2443.

24 Nakazato M, Murakami N, Date Y, Kojima M, Matsuo H, Kangawa K, Matsukura S: A role for ghrelin in the central regulation of feeding. Nature 2001;409:194-198.

25 Chen HY, Trumbauer ME, Chen AS, Weingarth DT, Adams JR, Frazier EG, Shen Z, Marsh DJ, Feighner SD, Guan XM, Ye Z, Nargund RP, Smith RG, Van der Ploeg LH, Howard AD, MacNeil DJ, Qian S: Orexigenic action of peripheral ghrelin is mediated by neuropeptide $\mathrm{Y}$ and agouti-related protein. Endocrinology 2004; 145:2607-2612.

26 Luquet S, Phillips CT, Palmiter RD: NPY/ AGRP neurons are not essential for feeding responses to glucoprivation. Peptides 2007; 28:214-225.

27 Tong Q, Ye CP, Jones JE, Elmquist JK, Lowell BB: Synaptic release of GABA by AGRP neurons is required for normal regulation of energy balance. Nat Neurosci 2008.

28 Lutter M, Sakata I, Osborne-Lawrence S, Rovinsky SA, Anderson JG, Jung S, Birnbaum S, Yanagisawa M, Elmquist JK, Nestler EJ, Zigman JM: The orexigenic hormone ghrelin defends against depressive symptoms of chronic stress. Nat Neurosci 2008;11: 752-753.

29 Zhao TJ, Liang G, Li RL, Xie X, Sleeman MW, Murphy AJ, Valenzuela DM, Yancopoulos GD, Goldstein JL, Brown MS: Ghrelin O-acyltransferase (GOAT) is essential for growth hormone-mediated survival of calorie-restricted mice. Proc Natl Acad Sci USA 2010;107:7467-7472.

-30 Liu J, Prudom CE, Nass R, Pezzoli SS, Oliveri MC, Johnson ML, Veldhuis P, Gordon DA, Howard AD, Witcher DR, Geysen HM, Gaylinn BD, Thorner MO: Novel ghrelin assays provide evidence for independent regulation of ghrelin acylation and secretion in healthy young men. J Clin Endocrinol Metab 2008;93:1980-1987.

31 Hassouna R, Zizzari P, Tolle V: The ghrelin/ obestatin balance in the physiological and pathological control of growth hormone secretion, body composition and food intake. J Neuroendocrinol 2010;22:793-804

- 32 Anderson KA, Ribar TJ, Lin F, Noeldner PK, Green MF, Muehlbauer MJ, Witters LA, Kemp BE, Means AR: Hypothalamic CAMKK2 contributes to the regulation of energy balance. Cell Metab 2008;7:377-388.

- 33 Andersson U, Filipsson K, Abbott CR, Woods A, Smith K, Bloom SR, Carling D, Small CJ: AMP-activated protein kinase plays a role in the control of food intake. J Biol Chem 2004;279:12005-12008. 
34 Lopez M, Lage R, Saha AK, Perez-Tilve D, Vazquez MJ, Varela L, Sangiao-Alvarellos S, Tovar S, Raghay K, Rodriguez-Cuenca S, Deoliveira RM, Castaneda T, Datta R, Dong JZ, Culler M, Sleeman MW, Alvarez CV, Gallego R, Lelliott CJ, Carling D, Tschop MH, Dieguez C, Vidal-Puig A: Hypothalamic fatty acid metabolism mediates the orexigenic action of ghrelin. Cell Metab 2008;7:389-399.

- 35 Kola B, Hubina E, Tucci SA, Kirkham TC, Garcia EA, Mitchell SE, Williams LM, Hawley SA, Hardie DG, Grossman AB, Korbonits M: Cannabinoids and ghrelin have both central and peripheral metabolic and cardiac effects via AMP-activated protein kinase. J Biol Chem 2005;280:25196-25201.

- 36 Kohno D, Sone H, Minokoshi Y, Yada T: Ghrelin raises [Ca2+]i via AMPK in hypothalamic arcuate nucleus NPY neurons. Biochem Biophys Res Commun 2008;366:388392.

- 37 Steinberg GR, Kemp BE: AMPK in health and disease. Physiol Rev 2009;89:1025-1078.

38 Obici S, Feng Z, Arduini A, Conti R, Rossetti L: Inhibition of hypothalamic carnitine palmitoyltransferase-1 decreases food intake and glucose production. Nat Med 2003; 9:756-761.

39 Wolfgang MJ, Lane MD: The role of hypothalamic malonyl-CoA in energy homeostasis. J Biol Chem 2006;281:37265-37269.

40 Ochoa JJ, Quiles JL, Ibanez S, Martinez E, Lopez-Frias M, Huertas JR, Mataix J: Agingrelated oxidative stress depends on dietary lipid source in rat postmitotic tissues. J Bioenerg Biomembr 2003;35:267-275.

-41 Sun Y, Asnicar M, Saha PK, Chan L, Smith RG: Ablation of ghrelin improves the diabetic but not obese phenotype of ob/ob mice. Cell Metab 2006;3:379-386.

-42 Sun Y, Butte NF, Garcia JM, Smith RG: Characterization of adult ghrelin and ghrelin receptor knockout mice under positive and negative energy balance. Endocrinology 2008; 149:843-850.

-43 Sun Y, Asnicar M, Smith RG: Central and peripheral roles of ghrelin on glucose homeostasis. Neuroendocrinology 2007;86:215228.

-44 Perreault M, Istrate N, Wang L, Nichols AJ, Tozzo E, Stricker-Krongrad A: Resistance to the orexigenic effect of ghrelin in dietaryinduced obesity in mice: reversal upon weight loss. Int J Obes Relat Metab Disord 2004;28:879-885.

$\checkmark 45$ Banks WA: The blood-brain barrier as a cause of obesity. Curr Pharm Des 2008; 14 : 1606-1614.

-46 Bouret SG, Gorski JN, Patterson CM, Chen S, Levin BE, Simerly RB: Hypothalamic neural projections are permanently disrupted in diet-induced obese rats. Cell Metab 2008;7: 179-185.
7 Sipols AJ, Baskin DG, Schwartz MW: Effect of intracerebroventricular insulin infusion on diabetic hyperphagia and hypothalamic neuropeptide gene expression. Diabetes 1995;44:147-151.

48 Martin TL, Alquier T, Asakura K, Furukawa N, Preitner F, Kahn BB: Diet-induced obesity alters AMP kinase activity in hypothalamus and skeletal muscle. J Biol Chem 2006;281: 18933-18941.

49 Briggs DI, Enriori PJ, Lemus MB, Cowley MA, Andrews ZB: Diet-induced obesity causes ghrelin resistance in arcuate NPY/ AGRP neurons. Endocrinology 2010;151: 4745-4755.

50 Banks WA, Burney BO, Robinson SM: Effects of triglycerides, obesity, and starvation on ghrelin transport across the blood-brain barrier. Peptides 2008;29:2061-2065.

51 Holst B, Cygankiewicz A, Jensen TH, Ankersen M, Schwartz TW: High constitutive signaling of the ghrelin receptor - identification of a potent inverse agonist. Mol Endocrinol 2003;17:2201-2210.

52 Petersen PS, Woldbye DP, Madsen AN, Egerod KL, Jin C, Lang M, Rasmussen M, BeckSickinger AG, Holst B: In vivo characterization of high basal signaling from the ghrelin receptor. Endocrinology 2009;150:49204930.

-53 Schwartz MW, Sipols AJ, Marks JL, Sanacora G, White JD, Scheurink A, Kahn SE, Baskin DG, Woods SC, Figlewicz DP, et al: Inhibition of hypothalamic neuropeptide $\mathrm{Y}$ gene expression by insulin. Endocrinology 1992; 130:3608-3616.

54 Minokoshi Y, Alquier T, Furukawa N, Kim YB, Lee A, Xue B, Mu J, Foufelle F, Ferre P, Birnbaum MJ, Stuck BJ, Kahn BB: Amp-kinase regulates food intake by responding to hormonal and nutrient signals in the hypothalamus. Nature 2004;428:569-574.

55 Flanagan DE, Evans ML, Monsod TP, Rife F, Heptulla RA, Tamborlane WV, Sherwin RS: The influence of insulin on circulating ghrelin. Am J Physiol Endocrinol Metab 2003; 284:E313-E316.

56 McCowen KC, Maykel JA, Bistrian BR, Ling PR: Circulating ghrelin concentrations are lowered by intravenous glucose or hyperinsulinemic euglycemic conditions in rodents. J Endocrinol 2002;175:R7-R11.

57 Luque RM, Kineman RD: Impact of obesity on the growth hormone axis: evidence for a direct inhibitory effect of hyperinsulinemia on pituitary function. Endocrinology 2006; 147:2754-2763.

58 Theander-Carrillo C, Wiedmer P, CettourRose P, Nogueiras R, Perez-Tilve D, Pfluger P, Castaneda TR, Muzzin P, Schurmann A, Szanto I, Tschop MH, Rohner-Jeanrenaud F: Ghrelin action in the brain controls adipocyte metabolism. J Clin Invest 2006;116: 1983-1993.

-59 Zarjevski N, Cusin I, Vettor R, Rohner-Jeanrenaud $F$, Jeanrenaud B: Chronic intracerebroventricular neuropeptide-Y administration to normal rats mimics hormonal and metabolic changes of obesity. Endocrinology 1993; 133:1753-1758.
60 Tschop M, Statnick MA, Suter TM, Heiman ML: GH-releasing peptide-2 increases fat mass in mice lacking NPY: indication for a crucial mediating role of hypothalamic agouti-related protein. Endocrinology 2002; 143:558-568.

61 Shrestha YB, Wickwire K, Giraudo S: Effect of reducing hypothalamic ghrelin receptor gene expression on energy balance. Peptides 2009;30:1336-1341.

62 Wortley KE, Anderson KD, Garcia K, Murray JD, Malinova L, Liu R, Moncrieffe M, Thabet K, Cox HJ, Yancopoulos GD, Wiegand SJ, Sleeman MW: Genetic deletion of ghrelin does not decrease food intake but influences metabolic fuel preference. Proc Natl Acad Sci USA 2004; 101:8227-8232.

63 Wortley KE, del Rincon JP, Murray JD, Garcia K, Iida K, Thorner MO, Sleeman MW: Absence of ghrelin protects against early-onset obesity. J Clin Invest 2005;115:35733578.

64 Zigman JM, Nakano Y, Coppari R, Balthasar $\mathrm{N}$, Marcus JN, Lee CE, Jones JE, Deysher AE, Waxman AR, White RD, Williams TD, Lachey JL, Seeley RJ, Lowell BB, Elmquist JK: Mice lacking ghrelin receptors resist the development of diet-induced obesity. J Clin Invest 2005;115:3564-3572.

65 Sun Y, Wang P, Zheng H, Smith RG: Ghrelin stimulation of growth hormone release and appetite is mediated through the growth hormone secretagogue receptor. Proc Natl Acad Sci USA 2004;101:4679-4684.

- 66 Pfluger PT, Kirchner H, Gunnel S, Schrott B, Perez-Tilve D, Fu S, Benoit SC, Horvath T, Joost HG, Wortley KE, Sleeman MW, Tschop MH: Simultaneous deletion of ghrelin and its receptor increases motor activity and energy expenditure. Am J Physiol Gastrointest Liver Physiol 2008;294:G610-G618.

67 Goldstone AP, Thomas EL, Brynes AE, Castroman G, Edwards R, Ghatei MA, Frost G, Holland AJ, Grossman AB, Korbonits M, Bloom SR, Bell JD: Elevated fasting plasma ghrelin in Prader-Willi syndrome adults is not solely explained by their reduced visceral adiposity and insulin resistance. J Clin Endocrinol Metab 2004;89:1718-1726.

68 Vestergaard ET, Gormsen LC, Jessen N, Lund S, Hansen TK, Moller N, Jorgensen JO: Ghrelin infusion in humans induces acute insulin resistance and lipolysis independent of growth hormone signaling. Diabetes 2008;57:3205-3210.

- 69 Pacifico L, Poggiogalle E, Costantino F, Anania C, Ferraro F, Chiarelli F, Chiesa C: Acylated and nonacylated ghrelin levels and their associations with insulin resistance in obese and normal weight children with metabolic syndrome. Eur J Endocrinol 2009;161: 861-870. 